\title{
THE EFFECT OF SYSTEMATIC FACTORS ON MILK YIELD IN SIMMENTAL COWS OVER COMPLETE LACTATIONS**
}

\author{
M. D. Petrović ${ }^{*}$, Z. Skalicki ${ }^{2}$, M. M. Petrović ${ }^{3}$, V. Bogdanović ${ }^{2}$ \\ ${ }^{1}$ Faculty of Agronomy, Cacak \\ ${ }^{2}$ Faculty of Agriculture, Belgrade \\ ${ }^{3}$ Institute for Animal Husbandry, Belgrade-Zemun \\ *Corresponding author: Milun Petrović, e-mail \\ ** Original scientific paper \\ Research was supported by the Ministry of Science and Environmental Protection of the Republic \\ of Serbia (Project No.: TR20042).
}

\begin{abstract}
The effect of systematic factors on production traits over complete lactations was investigated in 2,805 Simmental cows born in 1982 and onwards. The cows were housed at three farms in different areas: at the Zlatiborski Suvati dairy farm, Zlatibor, at the Dobricevo Agricultural Farm, Cuprija and at private farms in the region of Kotraze. The systematic factors (farm, calving season, lactation groups, group (year x season of birth), farm $\mathrm{x}$ calving season and farm $\mathrm{x}$ lactation group interactions) and age at first conception had statistically highly significant $(\mathrm{P}<0.001)$ effects on all complete lactation traits, with the exception of the effect of calving season on complete lactation duration $(\mathrm{P}<0.05)$ and milk-fat content $(\mathrm{P}>0.05)$. No statistically significant effect was produced by age at first conception on complete lactation duration and milk-fat content $(\mathrm{P}>0.05)$. Determination coefficients ranged from 0.100 in complete lactation duration to 0.361 in milk-fat content.
\end{abstract}

Key words: Simmental breed, milk yield, systematic effects.

\section{Introduction}

Performance traits in cows are analyzed through milk, milk-fat, protein and $4 \% \mathrm{FCM}$ production, as well as through the fat and protein content in complete and standard lactations. In view of the fact that milk yield is a polygenic quantitative trait that is dependent on genotype $(25 \%)$ and paragenetic factors $(75 \%)$, the variability of this trait is extremely high.

Cattle breeding procedures used today most commonly employ linear methods and models combining fixed parameters (year, farm, season, lactation) and random variables (the genetic impact of sire, an individual, etc.), which can 
be mutually dependent (related) or independent, with or without interactions, depending on the trait analyzed. The selected model results essentially in the breeding value of an individual (Bogdanović et al., 2003).

Non-genetic discontinuous factors (year, farm, season, lactation), depending on the level of production, sample size and mathematical statistical method used, can account for more than $50 \%$ of total variations in milk production (Stojić et al., 1996). Stojić et al. (1995), reported that farm, year and calving season induced $35.7 \%$ of total variations in milk production. Somewhat lower percentage of non-genetic factors (farm, year, calving season and order of lactation) $-22.7 \%$, in the total variability of production traits was found by Jovanovac (1987), whereas Hansen et al., 1983 reported a considerably higher percentage, i.e. about $45 \%$ (in terms of the farm-year-season effect).

\section{Material and Method}

The investigation of the effect of systematic factors on the expression of production traits of complete lactations included 2,805 Simmental cows born in 1982 and onwards. The cows were housed at three farms in different areas including the following:

-"Zlatiborski Suvati” dairy farm, Zlatibor,

- dairy farm at the Dobricevo Agricultural Farm, Cuprija, and

- private farms in the region of Kotraze.

The following production traits of complete lactations were examined:

- duration of lactation (DCL), (days),

- milk production in complete lactations (MPCL), $(\mathrm{kg})$,

- milk-fat content in complete lactations (MFCCL), (\%),

- milk-fat yield in complete lactations (MFYCL), (kg)

The study focused on the expression of production traits as affected by the following systematic factors:

o Breeding area. The effect of three localities (Zlatibor, Dobricevo and Kotraze farms) was examined.

o Lactation group. Lactation groups were established in order to obtain an equal number of heads of cattle in different lactations and reduce variability as much as it was possible:

- group I (first lactation), 
- group II (second lactation),

- group III (third lactation),

- group IV (fourth lactation),

- group V (fifth lactation),

- group VI (sixth and other lactations),

o Calving season, i.e. the onset of lactation (I-spring, II-summer, III-autumn, IV-winter season).

o Group (Interaction between the year of birth (cows that calved from 1982 to 1998) and season of birth (I-spring, II-summer, III-autumn and IV-winter season)).

o Interaction between the breeding area and the calving season (3 breeding areas $\mathrm{x} 4$ calving seasons).

o Interaction between the breeding area and the lactation group (3 breeding areas $\mathrm{x} 6$ lactation groups).

\section{o Age at first conception.}

The general linear model was used to analyze the effect of systematic environmental factors. The procedure enabled simultaneous analysis of a number of different effects, irrespective of their being either categorical or continuous factors by nature. The general linear model was based on the least squares method used in estimating the effects and hypothesis testing.

The effects of certain non-genetic factors on production traits of complete lactations were analyzed using the following model:

$$
\mathbf{y}_{\mathrm{ijkl}}=\boldsymbol{\mu}+\mathbf{O}_{\mathrm{i}}+\mathbf{L}_{\mathrm{j}}+\mathbf{G}_{\mathrm{k}}+\mathbf{S T}_{1}+\mathbf{O S T}_{\mathrm{il}}+\mathbf{O L}_{\mathrm{ij}}+\mathbf{b}_{\mathbf{1}}\left(\mathbf{x}_{\mathbf{1}}-\bar{x}_{\mathbf{1}}\right)+\mathbf{e}_{\mathrm{ijk} \mathrm{k}} \text {, where: }
$$

$\mathbf{y}_{\mathrm{ijkl}}$ - an individual of the i-th breeding area, $\mathrm{j}$-th lactation group, $\mathrm{k}$-th group, 1-th calving season,

$\boldsymbol{\mu}$ - grand mean of population, with the uniform presence of all classes of effects $(\mathrm{O}, \mathrm{L}, \mathrm{G}, \mathrm{ST}, \mathrm{OST}, \mathrm{OL})$,

$\mathbf{O}_{i}-$ fixed effects of the i-th breeding area (1-3),

$\mathbf{L}_{j}$ - fixed effect of the $j$-th lactation group (1-6),

$\mathbf{G}_{\mathrm{k}}$ - fixed effect of the k-th group (year of birth x calving season) (1-68),

$\mathbf{S T}_{1}$ - fixed effect of the 1-th calving season (1-4),

$\mathbf{O S T}_{\mathrm{il}}$ - fixed effect of the interaction between the i-th breeding area and the 1-th calving season (1-12),

$\mathbf{O L}_{\mathrm{ij}}$ - fixed effect of the interaction between the i-th breeding area and the $\mathrm{j}$ th lactation group (1-18), 
and

$\mathbf{b}_{1}-$ linear regression coefficient of the effect of age at first conception $\mathbf{e}_{\mathrm{ijkl}}-$ other undetermined effects.

\section{Results and Discussion}

Table 1 presents the results of analysis of the effect of systematic factors on the production traits of complete lactations, i.e. least-squares means (LSM), standard errors of the means $\left(\mathrm{SE}_{\mathrm{LSM}}\right)$ and significance of the effects analyzed.

Breeding area had a statistically very high significant effect $(\mathrm{P}<0.001)$ on all traits of complete lactations, which indicated that the corrections of production traits of complete lactations for the effect of this factor were justified. The highest production of milk, milk-fat and $4 \%$ fat-corrected milk was recorded in the Zlatibor cows due to their lactation duration being statistically very highly significantly $(\mathrm{P}<0.001)$ longer and due to more favourable effect of the free range system on the production traits. The highest milk-fat content was produced by the Kotraze cows which yielded the lowest amount of milk. Very significant $(\mathrm{P}<0.01)$ and significant $(\mathrm{P}<0.05)$ effects of the breeding area on the production traits of Simmental cows were reported by Petrović et al. (1997 and 2006), Perišić (1998), Rychen (1999), Chladek and Kucera (2000), Djurdjevic (2001), Djurdjevic et al. (2002) and Panic (2005). In her study of the effect of ambient factors on milk yield in complete and standard lactations in Simmental cows, Panic (2005) suggested that the effect of farm on both the milk-fat content and duration of complete lactations was not significant $(\mathrm{P}>0.05)$.

Calving season, i.e. the onset of lactation exhibited a statistically very highly significant effect $(\mathrm{P}<0.001)$ on milk production, milk-fat yield and $4 \%$ fat milk, significant effect $(\mathrm{P}<0.05)$ on the duration of lactations and insignificant effect $(\mathrm{P}>0.05)$ on the milk-fat content. Therefore, the calving season effect should be included in the model used in estimating the breeding value of dairy cows. Most authors (Ugur et al., 1995, Petrović et al., 1997, Saveli, 1997, Perišić, 1998, Kučera et al., 1999, Rychen, 1999, Djurdjevic, 2001, Gaydarska et al., 2001, Singh et al., 2001, Petrović et al., 2005, Panić, 2005 ) reported significant $(\mathrm{P}<0.05)$, highly significant $(\mathrm{P}<0.01)$ and very highly significant $(\mathrm{P}<0.001)$ effects of the calving season on the milk production and milk-fat yield, as opposed to few authors, such as Chladek and Kucera (2000), who underlined that the calving season did not affect significantly $(\mathrm{P}>0.05)$ the production traits of complete lactations. There is a great diversity of results on the effect of calving season on milk-fat content. 
Table 1. Least-squares means, standard errors of the means and significance of the effect of systematic factors and age at first conception on milk yield traits in cows over complete lactations

Milk yield traits in complete lactations

\begin{tabular}{|c|c|c|c|c|c|c|c|c|c|c|c|}
\hline \multicolumn{2}{|c|}{ Systematic effects } & \multicolumn{2}{|c|}{$\begin{array}{c}\mathbf{D C L} \\
\text { (days) }\end{array}$} & \multicolumn{2}{|c|}{$\begin{array}{c}\text { MPCL } \\
(\mathrm{kg})\end{array}$} & \multicolumn{2}{|c|}{$\begin{array}{c}\text { MFCCL } \\
(\%)\end{array}$} & \multicolumn{2}{|c|}{$\begin{array}{c}\text { MFYCL } \\
(\mathrm{kg})\end{array}$} & \multicolumn{2}{|c|}{$\begin{array}{c}\text { 4\%FCMCL } \\
(\mathrm{kg})\end{array}$} \\
\hline Farm & N & LSM & $\mathbf{S E}_{\text {LSM }}$ & LSM & $\mathbf{S E}_{\text {LSM }}$ & LSM & $\mathbf{S E}_{\mathrm{LSM}}$ & LSM & $\mathbf{S E}_{\text {LSM }}$ & LSM & $\mathbf{S E}_{\text {LSM }}$ \\
\hline I & 1968 & 334.15 & 1.73 & 4554.1 & 30.92 & 3.68 & 0.004 & 167.44 & 1.17 & 4333.7 & 29.81 \\
\hline II & 3237 & 289.09 & 1.50 & 3889.6 & 26.74 & 3.79 & 0.003 & 147.24 & 1.01 & 3763.4 & 25.77 \\
\hline III & 4513 & 293.42 & 1.28 & 3818.7 & 22.84 & 3.91 & 0.003 & 149.68 & 0.87 & 3773.4 & 22.02 \\
\hline \multicolumn{2}{|l|}{$F_{\text {exp }}$} & \multicolumn{2}{|c|}{$311.59^{* * * *}$} & \multicolumn{2}{|c|}{$268.71^{\text {*** }}$} & \multicolumn{2}{|c|}{$1562.2^{* * *}$} & \multicolumn{2}{|c|}{$133.86^{* * *}$} & \multicolumn{2}{|c|}{$183.42^{* * * *}$} \\
\hline \multicolumn{12}{|l|}{ Cal. season } \\
\hline I & 2281 & 306.55 & 1.67 & 4101.3 & 29.78 & 3.79 & 0.004 & 155.20 & 1.13 & 3968.5 & 28.70 \\
\hline II & 2642 & 305.81 & 1.56 & 4000.9 & 27.81 & 3.79 & 0.004 & 151.16 & 1.05 & 3869.6 & 26.80 \\
\hline III & 2269 & 307.42 & 1.52 & 4128.4 & 27.02 & 3.79 & 0.004 & 156.55 & 1.02 & 3999.6 & 26.04 \\
\hline IV & 2526 & 302.42 & 1.50 & 4119.1 & 26.83 & 3.80 & 0.003 & 156.24 & 1.02 & 3989.7 & 25.86 \\
\hline \multicolumn{2}{|l|}{$F_{\text {exp }}$} & \multicolumn{2}{|c|}{$3.16^{*}$} & \multicolumn{2}{|c|}{$6.61^{* * *}$} & \multicolumn{2}{|c|}{$2.20^{\mathrm{NS}}$} & \multicolumn{2}{|c|}{$8.23^{* * *}$} & \multicolumn{2}{|c|}{$7.32^{* * *}$} \\
\hline \multicolumn{12}{|l|}{ Lact. gr. } \\
\hline $\mathbf{I}(1)$ & 2800 & 313.88 & 1.35 & 3795.1 & 24.15 & 3.82 & 0.003 & 144.48 & 0.92 & 3685.5 & 23.27 \\
\hline II (2) & 2297 & 306.16 & 1.50 & 4035.8 & 26.83 & 3.80 & 0.003 & 152.72 & 1.02 & 3905.3 & 25.86 \\
\hline III (3) & 1715 & 306.09 & 1.72 & 4203.6 & 30.67 & 3.78 & 0.004 & 158.89 & 1.16 & 4067.8 & 29.56 \\
\hline IV (4) & 1213 & 302.84 & 1.99 & 4229.8 & 35.53 & 3.78 & 0.005 & 159.41 & 1.35 & 4083.6 & 34.25 \\
\hline V (5) & 799 & 301.96 & 2.36 & 4210.6 & 42.07 & 3.78 & 0.005 & 159.05 & 1.60 & 4070.7 & 40.55 \\
\hline VI (6 etc.) & 894 & 302.37 & 2.32 & 4049.8 & 41.35 & 3.80 & 0.005 & 154.16 & 1.57 & 3928.2 & 39.85 \\
\hline \multicolumn{2}{|l|}{$\mathbf{F}_{\text {exp }}$} & \multicolumn{2}{|c|}{$9.79^{* * * *}$} & \multicolumn{2}{|c|}{$44.82^{* * *}$} & \multicolumn{2}{|c|}{$23.70^{* * * *}$} & \multicolumn{2}{|c|}{$38.01^{* * * *}$} & \multicolumn{2}{|c|}{$41.48^{* * *}$} \\
\hline \multicolumn{12}{|c|}{ Group (Gr x Sb) } \\
\hline \multicolumn{2}{|l|}{$\mathbf{F}_{\text {exp }}$} & \multicolumn{2}{|c|}{$2.84^{* * *}$} & & & & & 5.5 & & 5.6 & \\
\hline Farm x Cal & seas. & & & & & & & & & & \\
\hline$F_{\text {exp }}$ & & 5.4 & $9^{* * * *}$ & 7.6 & & & & 7.5 & & 7.4 & \\
\hline Farm $x$ La & t.gr. & & & & & & & & & & \\
\hline$F_{\text {exp }}$ & & 6.6 & & 34.8 & $7^{* * * *}$ & & & 35.7 & & 35.9 & \\
\hline Age at 1st & onc. & & & & & & & & & & \\
\hline $\mathbf{F}_{\text {exp }}$ & & 0.00 & $4^{\mathrm{NS}}$ & 13. & $8^{* * * *}$ & & & 14.3 & & 14.1 & \\
\hline
\end{tabular}

Namely, the effect of the season was reported to be either insignificant (Petrović et al., 1997, Perišić, 1998, Đurđević, 2001, Petrović et al., 2005) or significant (Miščević, 1995, Singh et al., 2001), highly significant (Panić, 2005) and very highly significant (Gaydarska et al., 2001). 
The highest milk and milk-fat production, primarily due to the longest period of lactation, was recorded in the autumn season. Maximum production is achieved in winter and spring, and minimum in summer and autumn, the fact reported by most authors (Miščević, 1995, Perišić, 1998, Kučera et al., 1999, Petrović et al., 2005, Panić, 2005).

The order of lactation had a very high significant effect $(\mathrm{P}<0.001)$ both on milk and milk-fat yields and the milk-fat content and duration of lactation. The lowest and highest milk, milk-fat and $4 \%$ fat-corrected milk yields were recorded in the first and the fourth lactations, respectively. The minimum milk production in the first lactation induced the highest milk-fat content of the lactation. Highly significant and very highly significant effects of the order of lactation on milk and milk-fat production were reported by most researchers. Furthermore, most authors found that the order of lactation did not affect significantly $(\mathrm{P}>0.05)$ the milk-fat content (Perišić, 1998, Djurdjevic, 2001, Gaydarska et al., 2001 and Panić, 2005), as opposed to Petrović et al. (2005), who determined a very highly significant effect $(\mathrm{P}<0.001)$.

The effects of the group, i.e. the interaction between the year and season of birth, the interactions between farm and calving season and farm and lactation group on all milk yield traits of complete lactations were very highly significant $(\mathrm{P}<0.001)$. Therefore, the inclusion of both the above individual systematic factors and their interactions into models was justified. In their study of active Simmental population in Serbia, Petrovic et al. (1997), reported that the interaction between the breeding area and the calving season led to highly significant variations in milk and milk-fat yields $(\mathrm{P}<0.01)$. Most authors underlined the significant and highly significant effect of the year of birth on milk and milk-fat yield as a separate systematic factor, whereas Perisic (1998) emphasized that the year of calving did not have a statistically significant ( $P>0.05)$ effect on Simmental cow performance, small variations over the years and slightly pronounced positive genetic tendency being recorded.

The age at first conception as a continuous factor had a statistically very highly significant $(\mathrm{P}<0.001)$ effect on the milk, milk-fat and $4 \% \mathrm{FCM}$ production, and an insignificant effect $(\mathrm{P}>0.05)$ on the duration of complete lactations and their milk-fat content, as confirmed by studies of Petrović et al. (2005). An insignificant $(\mathrm{P}>0.05)$ random effect of the age at first conception on milk-yield traits over complete lactations was reported by Djurdjevic (2001) and Djurdjevic et al. (2002).

Table 2 presents the analysis of variance for the production traits of complete lactations, i. e. the significance of the examined factors, the sum of squares and the percentage of the sum of squares out of the total sum. The table also gives the coefficients of determination $\left(\mathrm{R}^{2}\right)$ which denote the remainder of the residual variance in the total variance divided by 100 . 
Table 2. The analysis of variance for the milk yield traits in complete lactations. Significance of factors, sum of squares, $\%$ of the total sum and coefficients of determination( $\left(R^{2}\right)$

\begin{tabular}{|c|c|c|c|c|c|c|}
\hline Traits & \multirow{2}{*}{$\begin{array}{c}\text { Degrees } \\
\text { of } \\
\text { freedom }\end{array}$} & \multirow{2}{*}{$\begin{array}{c}\text { DCL } \\
\text { (days) }\end{array}$} & \multirow{2}{*}{$\begin{array}{c}\text { MPCL } \\
(\mathbf{k g})\end{array}$} & \multirow{2}{*}{$\begin{array}{c}\text { MFCCL } \\
(\%)\end{array}$} & \multirow{2}{*}{$\begin{array}{c}\text { MFYCL } \\
(\mathrm{kg})\end{array}$} & \multirow{2}{*}{$\begin{array}{c}\text { 4\%FCMCL } \\
\text { (kg) }\end{array}$} \\
\hline Source & & & & & & \\
\hline Farm & 2 & $\begin{array}{c}* * * \\
2402196 \\
6.72\end{array}$ & $\begin{array}{c}* * * \\
939711800 \\
7.50\end{array}$ & $\begin{array}{c}* * * \\
85.500 \\
31.61\end{array}$ & $\begin{array}{c}* * * \\
604588 \\
3.51\end{array}$ & $\begin{array}{c}* * * * \\
571837300 \\
5.05\end{array}$ \\
\hline Calving season & 3 & $\begin{array}{c}* * * \\
34625 \\
0.10\end{array}$ & $\begin{array}{c}* * * \\
32538230 \\
0.26\end{array}$ & $\begin{array}{c}\mathrm{ns} \\
0.100 \\
0.04\end{array}$ & $\begin{array}{c}* * * \\
55405 \\
0.32\end{array}$ & $\begin{array}{c}* * * \\
32805310 \\
0.29\end{array}$ \\
\hline Lactation groups & 5 & $\begin{array}{c}* * * \\
194483 \\
0.54\end{array}$ & $\begin{array}{c}* * * \\
307037400 \\
2.45\end{array}$ & $\begin{array}{c}* * * \\
2.200 \\
0.81\end{array}$ & $\begin{array}{c}* * * \\
389391 \\
2.26\end{array}$ & $\begin{array}{c}* * * \\
268655500 \\
2.37\end{array}$ \\
\hline $\begin{array}{l}\text { Group (Yr. of birth } \\
\text { x S. of birth) }\end{array}$ & 67 & $\begin{array}{c}* * * \\
608326 \\
1.70\end{array}$ & $\begin{array}{c}* * * \\
575121800 \\
4.59\end{array}$ & $\begin{array}{c}* * * \\
8.600 \\
3.18 \\
\end{array}$ & $\begin{array}{c}* * * \\
787129 \\
4.57\end{array}$ & $\begin{array}{c}* * * \\
518729300 \\
4.58\end{array}$ \\
\hline $\begin{array}{c}\text { Farm } x \text { Calving } \\
\text { season }\end{array}$ & 6 & $\begin{array}{c}* * * \\
103713 \\
0.29\end{array}$ & $\begin{array}{c}* * * \\
50098730 \\
0.40\end{array}$ & $\begin{array}{c}* * * \\
0.400 \\
0.15\end{array}$ & $\begin{array}{c}* * * \\
70646 \\
0.41\end{array}$ & $\begin{array}{c}* * * \\
45158960 \\
0.40\end{array}$ \\
\hline $\begin{array}{c}\text { Farm } x \text { Lactation } \\
\text { groups }\end{array}$ & 10 & $\begin{array}{c}* * * \\
221199 \\
0.62\end{array}$ & $\begin{array}{c}* * * \\
368945600 \\
2.94\end{array}$ & $\begin{array}{c}* * * \\
0.700 \\
0.26\end{array}$ & $\begin{array}{c}* * * \\
543536 \\
3.16\end{array}$ & $\begin{array}{c}* * * \\
353330400 \\
3.12\end{array}$ \\
\hline $\begin{array}{l}\text { Age at first } \\
\text { conception }\end{array}$ & 1 & $\begin{array}{c}\mathrm{ns} \\
13 \\
0.00\end{array}$ & $\begin{array}{c}* * * \\
14775140 \\
0.12\end{array}$ & $\begin{array}{c}\mathrm{ns} \\
0.035 \\
0.01\end{array}$ & $\begin{array}{c}* * * \\
21918 \\
0.13\end{array}$ & $\begin{array}{c}* * * \\
13979180 \\
0.12\end{array}$ \\
\hline Model & 94 & $\begin{array}{c}* * * \\
3564555 \\
9.97 \\
\end{array}$ & $\begin{array}{c}* * * \\
2288229000 \\
18.26 \\
\end{array}$ & $\begin{array}{c}* * * \\
97.535 \\
36.06 \\
\end{array}$ & $\begin{array}{c}* * * \\
2472613 \\
14.36 \\
\end{array}$ & $\begin{array}{c}* * * \\
1804496000 \\
15.93 \\
\end{array}$ \\
\hline Residual variance & 9623 & $\begin{array}{c}32203264 \\
90.03\end{array}$ & $\mid \begin{array}{c}10240660000 \\
81.74\end{array}$ & $\begin{array}{c}172.945 \\
63.94\end{array}$ & $\begin{array}{c}14733387 \\
85.64\end{array}$ & $\begin{array}{c}513252000 \\
84.07\end{array}$ \\
\hline $\mathbf{R}^{2}$ & - & 0.100 & 0.183 & 0.361 & 0.144 & 0.159 \\
\hline
\end{tabular}

N.S. - $\mathrm{P}>0.05 ; *-\mathrm{P}<0.05 ; * *-\mathrm{P}<0.01 ; * * *-\mathrm{P}<0.001$

The percentage of farm in the total variance of milk yield traits in complete lactations ranged from $3.51 \%$ in milk-fat yield to $31.61 \%$ in milk-fat content. The calving season makes up a rather small percentage of the total variance of production traits in complete lactations ranging from $0.04 \%$ in milkfat content to $0.32 \%$ in milk-fat yield. The milk yield control in cattle in Norway conducted by Mchau et Syrstad (1991), suggested that the month of calving accounted for $2-3 \%$ of the total variability of production traits. 
The percentage of variance of interactions between systematic factors in the total variance of production traits was also found to be low, accounting for about $5 \%$ only in some traits, the smallest percentage in the total variance being attributed to the age at first conception which did not contribute to the variance of the duration of complete lactations (0.00004\%). Examining the effect of paragenetic factors on the production traits of complete lactations, Petrović et al. (2005), reported a considerably higher proportion of the lactation group variance in the total trait variance, ranging from $1.43 \%$ in the duration of lactation to $20.00 \%$ in milk production in complete lactations. Furthermore, the authors found a higher proportion of the calving season $(0.17-2.85 \%)$ and age-at-firstconception variances in the total variance of production traits over complete lactations.

The significance of the model used in correcting all production traits of complete lactations for the effect of systematic factors was very high $(\mathrm{P}<0.001)$, the proportion of variance in the total variance ranging from $9.97 \%$ in the duration of lactations to $36.06 \%$ in milk-fat content. A very high significance of the model in estimating the breeding value of Simmental cows with respect to milk production was found by Petrovic et al. (2005). The authors suggested that the model variance accounted for $2.69 \%$ to $23.16 \%$ of the total production trait variance, with regard to the duration of lactation and milk production, respectively.

Proportionally to the percentage of the model variance in the total variance of production traits of complete lactations, the calculated coefficients of determination $\left(\mathrm{R}^{2}\right)$ ranged from 0.100 in the duration of lactations to 0.361 in the milk-fat content. This suggested that the production traits of complete lactations were affected by an even greater number of factors that were not analyzed in this study. Petrovic et al. (2005), reported the coefficients of determination to range from $2.69 \%$ in the duration of lactation to $23.16 \%$ in milk production in complete lactations.

\section{Conclusion}

The model used in examining the effect of systematic ambient factors and cow age at first conception on the expression of production traits in complete lactations suggests the following:

0 The effect of the breeding area on the production traits in complete lactations was very highly significant $(\mathrm{P}<0.001)$. The highest milk and milk-fat production was recorded in the Zlatibor cows, and the lowest in the Kotraze ones which also gave the highest milk-fat content.

0 The calving season had a very highly significant effect $(\mathrm{P}<0.001)$ on milk, $4 \%$ FCM and milk-fat production, significant effect $(\mathrm{P}<0.05)$ on the 
duration of complete lactations, and an insignificant effect $(\mathrm{P}>0.05)$ on the milk-fat content in complete lactations. Maximum milk and milk-fat production was achieved in the autumn season, the reason being the longest duration of lactations.

o The effect of the order of lactation (lactation group) on all production traits in complete lactations was very highly significant $(\mathrm{P}<0.001)$. Maximum milk and milk-fat production was registered in the fourth lactation, and minimum, coupled with the highest milk-fat content, in the first one.

o The interactions between farm and calving season, farm and lactation group, and year and season of birth had a statistically very highly significant effect on all traits of complete lactations $(\mathrm{P}<0.001)$.

0 The age at first conception, as a continuous factor, had a statistically very highly significant effect $(\mathrm{P}<0.001)$ on milk, milk-fat and 4\% FCM production, its effect on the duration of complete lactations and milk-fat content being insignificant $(\mathrm{P}>0.05)$.

0 The model used in correcting the production traits of complete lactations for the effect of systematic factors was very highly significant $(\mathrm{P}<0.001)$. The proportion of the variance of the model in the total variance of certain production traits ranged from $9.97 \%$ in the duration of complete lactations to $36.06 \%$ in the milk-fat content.

o Coefficients of determination $\left(\mathrm{R}^{2}\right)$ for the production traits ranged from 0.100 in the duration of complete lactations to 0.361 in the milk-fat content.

\title{
UTICAJ SISTEMATSKIH FAKTORA NA MLEČNOST KRAVA SIMENTALSKE RASE U CELIM LAKTACIJAMA
}

\author{
M. D. Petrović, Z. Skalicki, M. M. Petrović, V. Bogdanović
}

\section{Rezime}

Ispitivanje uticaja sistematskih faktora na ispoljenost proizvodnih osobina celih laktacija obavljeno je kod 2805 krava simentalske rase rođenih od 1982. godine pa na dalje. Krave su smeštene na tri farme, odnosno područja: farmi muznih krava "Zlatiborski suvati" na Zlatiboru, Poljoprivrednom dobru Dobričevo u Ćupriji i području Kotraže na individualnim gazdinstvima. Sistematski faktori (farma, sezona telenja, grupe laktacija, grupa (godina x sezona rođenja), interakcije farma $\mathrm{x}$ sezona telenja i farma $\mathrm{x}$ grupe laktacija) i uzrast pri prvoj oplodnji statistički su vrlo visoko značajano $(\mathrm{P}<0.001)$ uticali na sve osobine punih laktacija, izuzimajući uticaj sezone telenja na trajanje punih laktacija 
$(\mathrm{P}<0.05)$ i sadržaj mlečne masti $(\mathrm{P}>0.05)$. Uzrast pri prvoj oplodnji nije statistički značajno uticao na trajanje celih laktacija i sadržaj mlečne masti u njima $(\mathrm{P}>0.05)$. Koeficijenti determinacije kretali su se od 0.100 kod trajanja celih laktacija do 0.361 kod sadržaja mlečne masti.

Ključne reči: simentalska rasa, mlečnost, sistematski uticaji.

\section{References}

BOGDANOVIĆ V., ĐEDOVIĆ R. (2003): Testiranje i metode procene priplodne vrednosti simentalskih bikova. Savremeni trendovi u mlekarstvu, Zbornik radova, str. 46-50. Zlatibor.

CHLADEK G., KUCERA J. (2000A): Ananalysis of some factors affecting the milk production of cows sired by Montbeliard sires in the Czech Republic. Acta Universitatis Agriculturae et Silviculturae Mendelianae Brunensis. 2000, 48: 5, 21 26; 10 ref.

ĐURĐEVIĆ R. (2001): Genetička analiza mlečnosti i reprodukcijskih svojstava krava simentalske rase. Doktorska disertacija. Poljoprivredni fakultet Novi Sad, 2001.

ĐURĐEVIĆ R., VIDOVIĆ V., ANTOV G., LATINOVIĆ D. (2002): Genetička varijabilnost perzistencije laktacije krava simentalske rase. Biotechnology in Animal Husbandry 18(5-6), p.9-15.

GAYDARSKA V., KRUSTEV K., SIMEONOVA S., IVANOV M. (2001): Influence of environmental and genetic factors on the milk yield and phenotypic and genotypic parameters of milk production in Black and White dairy cows in Bulgaria. Biotechnology in Animal Husbandry 17 (1-2), p. 11-15, 2001.

HANSEN L., FREEMAN A.E., BERGER P.J. (1983): Variances, Repeatabilites and Age Adjustmens of Yield and Fertility in Dairy Cattle. Journal of Dairy Science, 66, 281-292.

JOVANOVAC S. (1987): Utjecaj sistematskih faktora okoline na mliječnost krava Holstein-Friesian pasmine. Znanost i praksa u poljoprivrednoj i prehrambenoj tehnologiji 17(3-4), 303-314.

KUCERA J., HYANEK J., MIKSIK J., CERMAK V. (1999): The influence of the season of parturition on milk performance in Czech Pied cattle. Czech Journal of Animal Science. 1999, 44: 8, 343-350; 22 ref.

MCHAU K.W., SYRSTAD O. (1991): Production characteristics of Mpwapwa cattle. 2. Shape of the lactation curve. World Anim. Rev., 66: 49-54.

MIŠČEVIĆ B. (1995): Komponente varijansi, kovarijansi i genetski trend osobina mlečnosti tokom prve i kasnijih laktacija simentalske rase. Doktorska disertacija, Poljoprivredni fakultet, Novi Sad. 
PANIĆ J. (2005): Kvantitativno - genetička analiza svojstava mlečnosti krava simentalske rase. Poljoprivredni fakultet, Univerzitet u Novom Sadu (Magistarska teza).

PERIŠIĆ P. (1998): Reproduktivne i proizvodne osobine različitih genotipova krava simentalske rase. Magistarska teza, Poljoprivredni fakultet, Beograd-Zemun. PETROVIĆ M.M., LAZAREVIĆ R., LAZAREVIĆ LJ., ALEKSIĆ S., MIŠČEVIĆ B., PERKOVIĆ S. (1997): Proizvodni efekti selekcije aktivne populacije simentalskih goveda u Srbiji. Bootehnologija u stočarstvu, god. 13, Br. 3-4, str. 57-64, Beograd-Zemun.

PETROVIĆ M.M., SRETENOVIĆ LJ., PANTELIĆ V., ALEKSIĆ S., MIŠČEVIĆ B., BOGDANOVIĆ V., OSTOJIĆ D., PETROVIĆ D.M. (2006): Results of the Application of the Technology of Genetic Improvement of Simmental Cattle Population in Serbia. Biotechnology in Animal Husbandry 22(1-2), p 1-8, Belgrade-Zemun.

PETROVIĆ D.M., SKALICKI Z., BOGDANOVIĆ V., PETROVIĆ M.M., KURĆUBIĆ V. (2005): The Effect of Paragenetic Factors on Performance Traits in Complete Lactations in Simmental Cows. $8^{\text {th }}$ International Symposium Modern Trends In Livestock Production. Belgrade Zemun, Serbia and Montenegro, 5.8.10.2005. Biotechnology in Animal Husbrandy 21 (5-6), p 7-12, 2005.

RYCHEN M. (1999): A $6279 \mathrm{~kg}$ milk yield - where are the limits? SchweizerFleckvieh. 1999, No. 7, 26-39.

SAVELI O. (1997): Effects of calving season on evaluation of the breeding value of dairy cattle. Book of Abstracts of the $48^{\text {th }}$ Annual Meeting of the European Association for Animal Production, Vienna, Austrija, 25-28 August

SINGH D.,YADAV A.S., DHAKA S.S. (2002): Studies on milk production profile attributes affected by environment and heredity in crossbred cattle. $7^{\text {th }}$ World Congress on Genetics Applied to Livestock Production, Montpellier, France.

STOJIĆ P., LATINOVIĆ D., KATIĆ M., LAZAREVIĆ LJ., TRIFUNOVIĆ G., BESKOROVAJNI R, ĆIRIĆ M. (1996): Značaj korekcije heterogenih varijansi u oceni priplodne vrednosti krava i bikova. Biotehnologija u stočarstvu, vol.12 (1-2), str. 23-28.

STOJIĆ P., KATIĆ M., LAZAREVIĆ LJ., LATINOVIĆ D., TRIFUNOVIĆ G., BESKOROVAJNI R, BRKIĆ N. (1995): Ponovljivost dnevnih prinosa mleka tokom laktacije crno belih krava. Prvi Simpozijum za oplemenjivanje organizama sa međunarodnim učešćem. Vrnjačka Banja.

UGUR F., YANAR M., OZHAN M., TUZEMEN N., AYDIN R., AKBULUT O. (1995): Milk production characteristics of Simmental cattle reared in the research farm of Ataturk University. Turk Veterinerlik ve Hayvancilik Dergisi. 1995, 19: 5, 365-368; 26 ref. 